\section{Miloš Stojanović ${ }^{1}$}

Marina Đorđević ${ }^{2}$

University of Niš

Faculty of Economics
SCIENTIFIC REVIEW ARTICLE doi:10.5937/ekonomika1604075S

Received: October 30, 2016

Accepted: November 22, 2016

\title{
THE ROLE OF ENVIRONMENTAL TAXES IN SERBIAN TAX SYSTEM
}

\begin{abstract}
The aim of this paper is to point out the lack of giving importance to ecological taxes and the low participation of dedicated revenues in the structure of these taxes in the tax system of the Republic of Serbia. Environmental taxes have gained in importance, especially through the ecological tax reform in a number of European countries, which have proved to be significantly more effective compared to other available instruments in the struggle against environmental problems. The premise of this paper is that the inadequate structure of environmental taxes has a negative impact on allocations in the field of environmental protection. This hypothesis will be tested by using statistical methods and comparative analysis.
\end{abstract}

Key words: environmental taxes, Republic of Serbia, ecological tax reform, excise.

JEL Classification: H21, H50, Q01, Q57

\section{УЛОГА И ЗНАЧАЈ ЕКОЛОШКИХ ПОРЕЗА У ПОРЕСКОМ СИСТЕМУ СРБИЈЕ}

\begin{abstract}
Apstrakt
Циљ овог рада је да укаже на недовољно давање значаја еколошким порезима као и ниско учешће наменских прихода у структури ових пореза у пореском систему Републике Србије. Еколошки порези су добили на значају, нарочито кроз еколошку пореску реформу у великом броју европских држава, где су се показали знатно ефикаснијим у односу на остале доступне инструменте у борби са еколошким проблемима. Полазна хипотеза овог рада је да неадекватна структура еколошких пореза има негативан утицај на издвајања у области заштите животне средине. Ова хипотеза ће бити тестирана употребом статистичких метода и компаративном анализом.
\end{abstract}

Kljuс̌nе rес̌і: еколошки порези, Република Србија, пореска еколошка реформа, акичизе.

\footnotetext{
${ }^{1}$ milos.s87@hotmail.com

${ }^{2}$ marinadj@ptt.rs
} 


\section{Introduction}

Contemporary humankind is facing a number of serious environmental problems. These problems have arisen as a result of ongoing efforts to increase current economic wealth and insufficient care for the environment in the past. This is why in a number of EU member states, as well as some of the countries that are not members of the EU has been a greening of the tax system through the ecological tax reform. In contrast to these European countries, the Republic of Serbia did not carry out an environmental tax reform. Therefore тo ecological taxes and to environmental problems, opposed to the EU Member States, Serbia do not give enough importance.

In the Republic of Serbia within the framework of the environmental taxes from the fiscal point of view is dominated the excise tax on petroleum products. As is well known that excise taxes, as a kind of public revenues do not have a dedicated character, and are not used for the realization of environmental objectives, but for the satisfaction of the usual needs of the state. Particularly big problem is that in Serbia there is no adequate differentiation of rates for the taxation of different types of petroleum products according to their environmental friendliness, which is not the case when the $\mathrm{EU}$ countries are concerned. Also insufficient participation of dedicated revenues in total environmental taxes and very often inadequate spending of earmarked funds make the process of solving environmental problems in Serbia even more complex.

\section{The concept and importance of environmental taxes}

Taxes are the most important public revenue of all modern states. In modern conditions in addition to its basic functions, to cover public expenditure, some types of taxes received and other functions (social, health, environmental, development). So there are a number of taxes, which are defined as ecological, and where environmental function is even more important than their fiscal functions.

Green taxes (environmental taxes or taxes on pollution) are charges paid by polluters of the environment or which are paid on goods which use pollutes the environment. Such taxes are introduced in order to reduce the occurrence of external effects, such as pollution and are called corrective or Pigouvian taxes. Green taxes do not only generate income, they also help in connecting private incentives and social benefits, which leads to improved overall efficiency of the economy (Stiglitz, 2004).

In a broader sense environmental taxes include environmental charges and fees, and even registration fees, fees for non-compliance with environmental standards, given that these instruments have the impact that they bring environmental standards to a higher level (OECD, 2006).

Environmental charges, or fees for environmental protection are payments for specific services such as waste collection, sewage treatment and collective facilities for water purification (Barde, 2004). Unlike environmental charges, environmental taxes are in most countries as a whole revenue of the state budget, whereas in the case of charges this is not so. Also unlike environmental taxes, charges have a predetermined purpose. So in a broad sense environmental charges are part of a package of environmental tax reform and a part of the environmental taxes. In the strictest sense there is a difference between environmental charges and environmental taxes (Maatta, 2006). 
Environmental taxes are the subject of interest of many ecologists and economists for a long time because they can contribute to increasing the quality of the environment. These taxes are more efficient and cheaper instrument than other instruments for the protection of the environment. But they besides this benefit create conditions for the realization of additional positive effect with regard of providing additional tax revenues (Kronenberg, 2007).

The additional tax revenue that the state provide by a green tax reform, or by greening of the tax system can be used in different ways. As some of the uses of these revenues, can be mentioned: investment in clean environment, investment in research and development of new techniques and technologies, investment in education in order to develop environmental awareness etc. (Goulder, 1995).

However, if we look at the countries that have implemented environmental tax reform, it can be seen that these additional tax revenues are most often used as a basis for the reduction of other taxes, which already exist in the tax system. These countries' goals were to ensure revenue neutrality. This was done by decreasing tax revenues (by reducing tax rates or narrowing of the tax base) of the existing taxes, which was offset by the same amount of tax revenue growth from environmental taxes (Bovenberg, de Mooij, 1994).

\section{Excise taxes as a part of the environmental taxes in the Republic of Serbia}

In Serbia, excise taxes which are defined as a part of environmental taxes are:

- Excise duties on petroleum products and

- Excise duties on electricity.

Excise duties on petroleum products certainly represent the most significant excise tax in fiscal term, as can be seen from the graph 1. From this graph it is clear that revenues from excise taxes on petroleum products account the half of total excise revenues, suggesting to their significance as the most abundant of excise revenues (Đurović-Todorović, Đorđević, 2013). This high share of excise taxes on petroleum products in excise tax revenues and excise revenues in total revenues in the budget shows that in the Republic of Serbia are set a high excise tax rates, as well as that consumption of this products, covered by the excise taxes, are quite high.

Excise duties on petroleum products, as has been said are the part of environmental taxes. However, unlike most EU countries, in the Republic of Serbia is not made adequate differentiation of tax rates. That means that it is not high enough range between the tax rates for different types of petroleum products, depending on that how their consumption affect the environment. 
Graph. 1. The share of revenues from excise taxes on petroleum products in total revenues from excise taxes in the Republic of Serbia, 2008-2015.

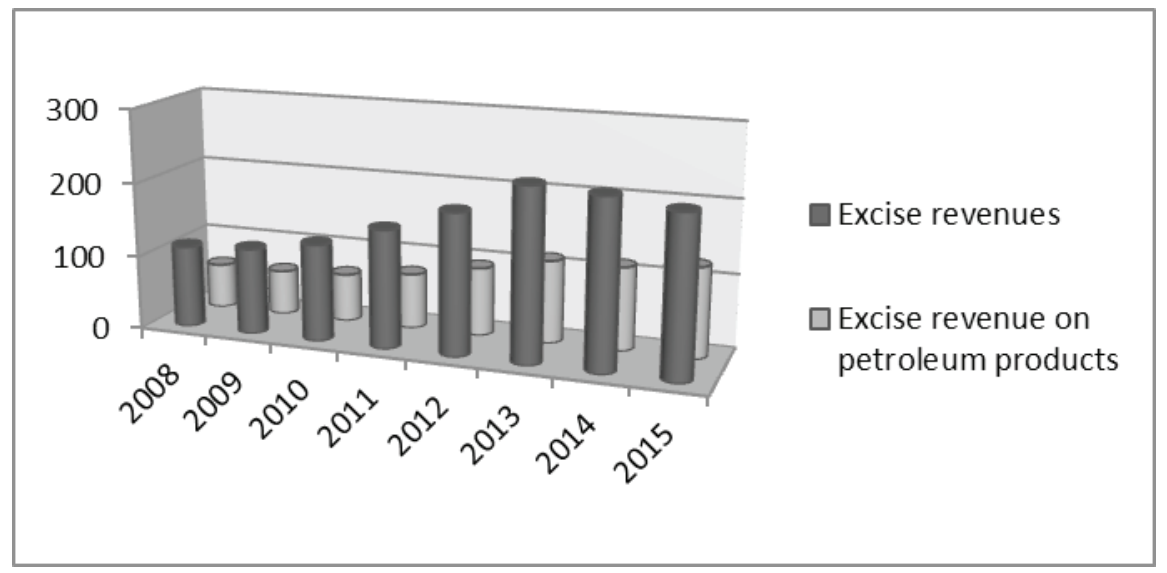

Source: Budget of the Republic of Serbia for 2008-2015., Illustrated by the authors.

In European Union countries the rate of excise duty on liquid petroleum gas, which is considered to be ecological fuel since it emits a smaller amount of harmful particles in the air, is several times lower than for example for leaded and unleaded gasoline. In the Republic of Serbia this is not the case. Of the EU countries only Sweden and Denmark have higher excise duty on liquid petroleum gas compared to Serbia. According to the recommendations of European Commission for liquid petroleum gas as motor fuel is a stipulated minimum rate of $125 €$ per tonne (European Commission, 2015). In Serbia excise tax for this fuel is much higher, given that for one ton of liquid petroleum gas tax rate is $333 €$ (Stojanović, 2016).

In Slovenia, for liquid petroleum gas prescribed rate of excise duty is 0.1275 euro per kilo (OECDa, 2012), while for unleaded gasoline is 0.485 euros per liter (El-Agraa, 2011). Thus spread between rates is quite high, with a view to encouraging the use of liquid petroleum gas. The reason is good environmental characteristics of LPG compared to other types of fuel.

This comparison suggests that it is not enough the excise taxes just to be high, in order to achieve positive effects on the quality of the environment. It is well known that the price elasticity of demand for energy products is rather low. And for achieving positive effects for the environment, it is essential that the alternative fuels which less pollute the environment, to be taxed at lower rates. This milder taxation in the analyzed case of liquefied petroleum gas would enable through the cross-elasticity of demand, to come to growing demand for this fuel. This would lead to reduction in demand for other fuels which can be substituted with LPG, what would ultimately have positive effects on the reduction of greenhouse gas emissions.

In the latest amendments to the Law on Excise Duties were introduced excise tax on electricity consumption (Zakon o akcizama, čl. 2). From 1 August 2015 it is introduced the payment of excise tax on final electricity consumption at a rate of $7.5 \%$. Under the final consumption of electricity, in accordance with the Law is considered delivery of electricity to the final consumers in the Republic of Serbia, but also the consumption of 
electricity by the supplier for its own purposes calculated on the basis of consumption reading through measuring devices.

The basis for the calculation of excise duty on electricity is quite broadly defined (Centar za zaštitu potrošača „Forum” Niš, 2015). This is the reason why this excise is criticized in the public. Center for Consumer Protection "Forum" in Nis, indicates that excise duty should not be levied on other elements of the tariff system, but only on the basis of the number of kilowatt hours of electricity consumed. They emphasize that these other elements do not have any connection to the electricity consumed energy.

Among the other things, this excise duty has an impact on the decline in demand, which before its introduction was not enviable. The fall in demand has definitely a negative impact on other economic trends in the economy. So the exclusion of other elements, except the actual consumption of kilowatt hours of electricity, would alleviate the negative effects.

In addition to these negative implications of the newly introduced excise duty on electricity, there are some facts that may be described as positive. The introduction of the excise tax, in fact represents one segment of our alignment with the tax system of the European Union. It is also positive that through this excise great importance is given to renewable energy sources.

\section{Ecological charges in the Republic of Serbia}

Environmental charges are part of a system of environmental taxes in a broad sense, in accordance with the Law in the Republic of Serbia are prescribed the following charges (Zakon o zaštiti životne sredine, čl. 84, 85 i 87):

- charge for use of natural resources;

- charge for environmental pollution and

- charge for the protection and improvement of the environment.

All of these charges are earmarked revenues, which means that their purpose is predetermined and are used for the protection and improvement of the environment. The aim of the charges as an economic instruments of environmental protection is to promote the reduction of environmental damage, based on respecting the principle of "polluter pays" and "user pays" (Andre, Delisle, Reveret, 2004).

By 2012, part of the charges that were collected at the national level, were streamed into the Fund for Environmental Protection. From this Fund they were deployed for specific projects and programs in the environmental field. However, from the entry into force the Suspension of the Law on the Fund for Environmental Protection, the Fund for Environmental Protection has ceased to exist. So the charges that are related to environmental protection, have become the general revenue in the budget (Zakon o prestanku važenja Zakona o Fondu za zaštitu životne sredine).

Revenues from charges have a great importance for the preservation and improvement of the quality of the environment, given that in total expenditure for the environment in the Republic of Serbia participate with 32\%, based on data for 2014. In total sources of financing protection and improvement of the environment, the largest share of expenditures are from the budget for these purposes $36 \%$. The sectors of the economy allocates $19 \%$, and international donations $13 \%$ of the funds invested for this purpose (Krunic-Lazic, 2015). 
Revenues from charges in 2014 amounted $0.27 \%$ of gross domestic product. The total funds intended for environmental protection in the same year amounted $0.85 \%$ of gross domestic product. What is also negative is that the funds that were intended for the environment protection in 2013 was higher for 21\% compared to funds for 2014 (KrunicLazic, 2015). These allocation of funds are considered to be quite low. Unlike the Republic of Serbia, national allocations at EU level are amounted about 2.1\% of GDP for environmental protection (Eurostat, 2016). It is necessary in the future to give to this question further attention in Serbia, in order to achieve the same level of environmental care as in the European Union.

\section{Analysis of environmental taxes and expenditures for the environment in Serbia}

Revenues from the tax groups, which are among the environmental taxes in Serbia are fiscal significance. On the other hand, only a small portion of the revenues are set aside by the state in the field of environmental protection. One reason for this situation is that most of the revenues from environmental taxes is collected from excise taxes on petroleum products, which do not have a dedicated character, as is the situation in Turkey (OECDb, 2012). Also, a large number of economic problems Serbia is faced with, have the influence on the allocation of revenues in other areas.

Analysis of the situation of environmental taxation in the RS in the paper is implemented by graphical analysis, descriptive statistics, as well as through comparison of the expenditures for environmental protection in Serbia compared to other countries, with the aim to determine what is the position of Serbia in this field.

On graph 2, it can be seen that there are significant deviations from the trend line, indicating a weak correlation between those two variables. Or in the Republic of Serbia in some years the revenues are higher than in the other analyzed years, but expenditure in those years is much lower, and vice versa.

Graph. 2 Diagram of dispersion revenue from eco-taxes and government expenditures in the environmental field for the period 2006-2013. in RS

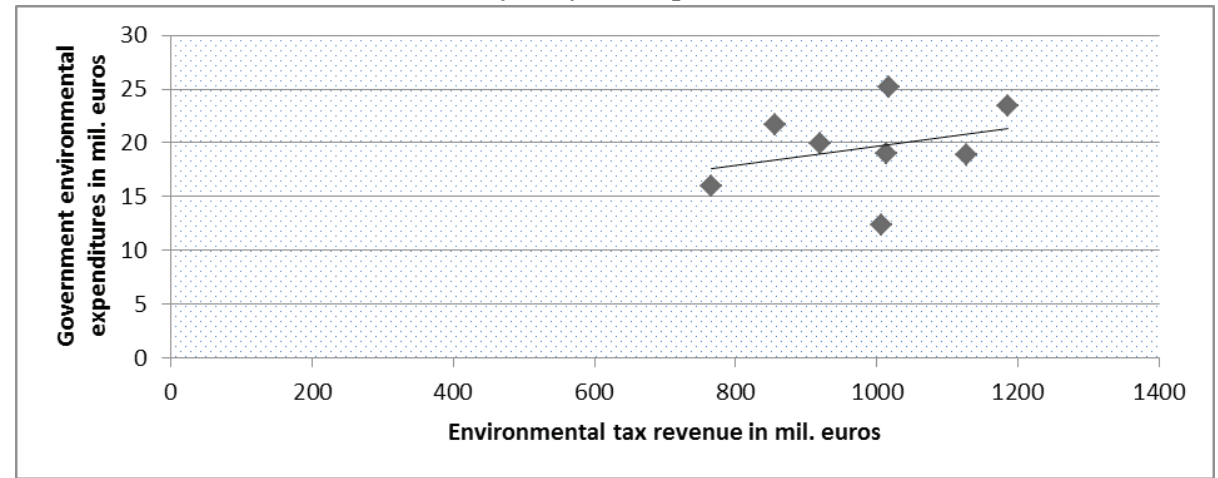

Source: http://ec.europa.eu/eurostat, access date 20/03/2016. The diagram illustrated by the authors. 
Based on the results shown in the table no. 1, it can be seen that in the observed period the average income from eco taxes was amounted to 986.77 million euros. In the same period, the average expenditure for environmental protection by the state was amounted to 19.56 million euros. The median, show us the value which separate the higher half of a data sample, from the lower half. In this example median for income equals $1,010.530$, or 19.48 million euros in the case of expenditure.

The largest amount of revenues from environmental taxes, which was collected on an annual basis was 1186.58 , and the least 766.18 million euros. In the case of the maximum amount of expenditure was 25.22 , and 12.37 million euros was minimum on an annual basis.

The standard deviation is high in the case of both observed variables, indicating that there are significant deviations from the average value calculated for the observed period.

The coefficient of skewness is negative for both variables. It suggests that the distribution of frequencies is shifted to the left. Kurtosis indicates that the distribution curve is less convex. Jarque-Bera test shows that there is a normal distribution of frequency.

Table. 1 Results of descriptive statistics, revenue from environmental taxes and expenditures for environmental protection by the government in the Republic of Serbia, 2006-2013.

\begin{tabular}{|l|c|c|}
\hline & Exp_for_envl_protection & Rev_from_env_taxes \\
\hline Mean & 19.56375 & 986.7675 \\
\hline Median & 19.47500 & 1010.530 \\
\hline Maximum & 25.22000 & 1186.580 \\
\hline Minimum & 12.37000 & 766.1800 \\
\hline Std. Dev. & 4.089170 & 137.2295 \\
\hline Skewness & -0.383621 & -0.144924 \\
\hline Kurtosis & 2.403167 & 2.143987 \\
\hline & & 0.272257 \\
\hline Jarque-Bera & 0.314957 & 0.872731 \\
\hline Probability & 0.854295 & 8 \\
\hline Observations & 8 & $p$ \\
\hline
\end{tabular}

Source: Stojanović, M., Efikasnost poreza u rešavanju ekoloških problema.

In countries that have implemented environmental tax reform, percentage share of expenditures for environmental protection in the harvested revenues from environmental taxes have a significant participation. In the Republic of Serbia it is not the case. Table no. 2 shows that participation by years in Serbia and as it can be seen in data presented, percentage share was ranged from $1.23 \%$ in 2010 to $2.53 \%$ in 2007 . 
Table. 2 Overview of revenues and expenditures for environmental protection in Serbia, 2006-2010.

\begin{tabular}{|r|r|r|r|}
\hline Year & $\begin{array}{c}\text { Environmental tax } \\
\text { revenues (mill. } € \text { ) }\end{array}$ & $\begin{array}{c}\text { Government } \\
\text { environmental } \\
\text { expenditures (mill. } € \text { ) }\end{array}$ & $\begin{array}{c}\text { Percentage } \\
\text { share }\end{array}$ \\
\hline 2006 & 766,18 & 15,95 & 2,08 \\
\hline 2007 & 856,66 & 21,67 & 2,53 \\
\hline 2008 & 919,25 & 19,94 & 2,17 \\
\hline 2009 & 1.014 & 19,01 & 1,87 \\
\hline 2010 & $1.007,06$ & 12,37 & 1,23 \\
\hline 2011 & $1.126,98$ & 18,92 & 1,68 \\
\hline 2012 & $1.017,43$ & 25,22 & 2,48 \\
\hline 2013 & $1.186,58$ & 23,43 & 1,97 \\
\hline
\end{tabular}

Source: Stojanović, M., Efikasnost poreza u rešavanju ekoloških problema.

With the aim of comparing the situation in Serbia with some of both developed and developing countries, in Table. 3 is shown percentage share of expenditures for environmental protection in the harvested revenues from environmental taxes by countries in 2007.

As can be seen from the table in selected developed countries share ranges is from $11 \%$ to $24.4 \%$. From developing countries the situation is favorable from an environmental aspect in Chile, where $10 \%$ of eco tax revenue is allocated for environmental protection by the State. In Turkey the situation is extremely unfavorable and participation for 2007 amounts only $0.69 \%$ of environmental tax revenue.

Table. 3 The percentage share of expenditure for the environment in the revenues from environmental taxes in selected countries in 2007

\begin{tabular}{|l|r|}
\hline \multicolumn{1}{|c|}{ Country } & \multicolumn{2}{|c|}{ Percentage share } \\
\hline Germany & 24,43 \\
\hline Finland & 11 \\
\hline Estonia & 13,54 \\
\hline Slovenia & 11,86 \\
\hline Norway & 25 \\
\hline Sweden & 19,55 \\
\hline Chile & 10,9 \\
\hline Turkey & 0,69 \\
\hline Serbia & 2,53 \\
\hline
\end{tabular}

Source: Stojanović, M., Efikasnost poreza u rešavanju ekoloških problema.

This presented situation in the field of environmental protection in the Republic of Serbia, certainly is not commendable. Therefore in the future in this area should be made significant reforms, with the aim to harmonize national practices with EU practice. 


\section{Conclusion}

Environmental taxes are very important in solving environmental problems. Through these taxes, their taxpayers are encouraged to change their behavior in terms of its compliance with the requirements of health and environmental quality. But in Serbia, despite significant fiscal abundance of these taxes, primarily due to the excise tax on petroleum products, their ecological role is significantly limited.

The main reasons for this limitation is the poor differentiation of tax rates according to environmental criteria. Especially when the excise duty on petroleum products are taken into consideration. Also a small financial participation of dedicated revenue in total environmental taxes makes this limitation bigger. In order to resolve this situation it is necessary for Serbis in line with the EU: to perform more adequate differentiation of tax rates for environmental taxes, provide better design of existing taxes and charges and to introduction new charges, provide better control of spending earmarked funds, and to allocate more funds from non-dedicated part of revenues for environmental protection in Serbia.

\section{References}

Andre, P., Delisle, C., Reveret, J. P. (2004), Environmental Assessment for Sustainable Development: Processes, Actors and Practice, Presses Internationales Polytechnique, Montreal.

Barde, J. P. (2004) Green tax reforms in OECD countries: an overview, Taller Regional de Politica Fiscal y Medio Ambiente en America Latina y el Caribe, Santiago de Chile.

Bovenberg, A. L., de Mooij R. A. (1994) Economic Levies ans Distortionary Taxation, The American Economic Review, Vol. 84, No. 4, American Economic Association.

Centar za zaštitu potrošača „Forum” Niš (2015) Umesto akcize na električnu energiju EPS snadbevanje zaračunava akcizu na tarifni sistem, available on: http://www. forum-nis.org.rs, date of access 24.08.2016.

Đurović-Todorović, J. Đorđević, M. (2013) Porezi na potrošnju, Ekonomski fakultet Niš.

El-Agraa, A. M. (2011) The European Union Economics and Policies, Cambridge University Press, Cambridge.

European Commision (2015) Excise duty tables - Part II Energy products and Electricity, Brussel.

Eurostat (2016) Environmental Protection Accounts, available on: http://ec.europa. eu/eurostat/statistics-explained/index.php?title=Environmental_protection expenditure_accounts\&oldid=303348, date of access 11.09.2016.

Goulder, L.H. (1995) Environmental Taxation and the "Double Dividend": A Reader's Guide International Tax and Public Finance, 2(2), National Bureau of Economic Research, Cambridge, available on: http://www.nber.org/papers/w4896.pdf, date of access 11.09.2016.. 
Kronenberg, T. (2007) Reconciling Environmental Conservation with Economic Prosperity: The Feasibility of Double Dividends in the Short and Long Run, Forschungszentrum Julich GmbH, Verlag.

Krunić, L. M. (2015) Izveštaj o ekonomskim instrumentima za zaštitu životne sredine u republici Srbiji, Ministarstvo poljoprivrede i zaštite životne sredine, Beograd.

Maatta, K. (2006) Environmental Taxes: An Introductory Analysis, Edward Elgar, Cheltenham.

OECDa (2012) OECD Environmental Performance Reviews: Slovenia 2012, OECD Publishing, Paris.

OECDb (2012) OECD Economic Surveys: Turkey 2012, OECD Publishing, Paris.

OECD (2006) The Political Economy of Environmentally Related Taxes, OECD Publishing, Paris.

Stiglic, E. J. (2004) Ekonomija javnog sektora, Ekonomski fakultet Zagreb, Zagreb.

Stojanović, M. (2016) Efikasnost poreza u rešavanju ekoloških problema, neobjavljena doktorska disertacija, Ekonomski fakultet Niš.

Tatić - Poreska kancelarija. (2015) Porezi i računovodstvo - časopis o primeni propisa u praksi, Beograd.

Zakon o zaštiti životne sredine, „Službeni glasnik RS“ br. 135/2004, 36/2009 -dr. Zakon, 72/2009 - dr. Zakon i 43/2011 - odluka US.

Zakon o prestanku važenja Zakona o Fondu za zaštitu životne sredine, „Službeni glasnik RS“, brojj 72/09 и 101/11.

Zakon o akcizama, (“Sl. glasnik RS”, br. 22/2001, 73/2001, 80/2002, 43/2003, 72/2003, 43/2004, 55/2004, 135/2004, 46/2005, 101/2005 - dr. zakon, 61/2007, 5/2009, 31/2009, 101/2010, 43/2011, 101/2011, 6/2012 - usklađeni din. izn., 43/2012 - odluka, 76/2012 - odluka, 93/2012, 119/2012, 8/2013 - usklađeni din. izn., 47/2013, 4/2014 - usklađeni din. izn., 68/2014 - dr. zakon, 142/2014, 4/2015 - usklađeni din. izn., 5/2015 - usklađeni din. izn., 55/2015, 103/2015 i 5/2016 usklađeni din. izn.) 